\title{
PARTIAL CLONING AND IDENTIFICATION OF TERPENE SYNTHASE-6 GENE (TPS-6) IN AN AROMATIC PLANT Origanum onites L.
}

\author{
İsmail POYRAZ*, Merve SAĞLAM \\ Molecular Biology and Genetics Department, Bilecik Seyh Edebali University, 11210, Bilecik. \\ *Corresponding author: e-mail: ismail.poyraz@bilecik.edu.tr
}

Received (Alınış): 13 Fab 2017, Accepted (Kabul): 13 Oct 2017, Online First (Erken Görünüm): 20 Oct 2017, Published (Basım): 15 Dec 2017

\begin{abstract}
Origanum onites L. (oregano) is an aromatic plant used in medicine, cosmetics and different industrial fields. It includes essential oil and is extensively cultivated as aromatic plant in the world. Therefore, it is also preferred as a spice in foods. Terpene synthase-6 (TPS-6) is an enzyme responsible for synthesis of sesqui-terpenes in aromatic plants. The investigation of gene sequence information and expression characteristics of this enzyme in $O$. onites may contribute to increase of synthesis of terpenes as raw materials in medicine and cosmetic etc. industry. In this study, partial cloning and sequencing of the TPS-6 gene in the $O$. onites was aimed. Total RNA isolation from $O$. onites was performed with TRI Reagent solution. The mRNAs were transformed to cDNAs by Revers Transcription Method. The middle region of TPS-6 gene was amplified by PCR method using degenerative primers designed for TPS-6. Amplified DNA fragments were obtained at $481 \mathrm{bp}$. size and ligated to PGEM T Easy plasmid vector with T4 DNA ligase. The recombinant plasmid vector was transferred to the XL1Blue host cells (E. coli) and the cloned DNA was sequenced. The partial TPS-6 DNA sequence was confirmed in NCBI GenBank database and registered with an accession number (MF983853). The obtained DNA sequence was analyzed with InterProScan and Clustal Omega software in EBI database. The analysis results showed that this DNA sequence has a specific motif (DXXD) for TPS-6 catalyzing cyclization reactions. The phylogenetic dendrogram was drawn for comparison with other plant TPS-6 genes. $O$. onites TPS-6 sequence was determined to be very close to $O$. vulgare TPS- 6 on the dendrogram than other plant TPS-6s. The obtained gene sequence information will guide biotechnological researches in the productivity increase of this gene using expression analysis.
\end{abstract}

Key words: Origanum onites, TPS-6, Gene cloning, DNA sequencing.

\section{Bir Aromatik Bitki Origanum onites L.'de Terpen Sentaz-6 (TPS-6) Geninin Kısmi Klonlanması ve Tanımlanması}

\begin{abstract}
Özet: Origanum onites L. (kekik), tıp, kozmetik ve farklı endüstri alanlarında kullanılan aromatik bir bitkidir. Uçucu yağ içerir ve dünyada aromatik bir bitki olarak yaygın kültüre edilir. Bu yüzden yiyeceklerde bir baharat olarak da tercih edilir. Terpen sentaz-6 (TPS-6), aromatik bitkilerde sesqui-terpenlerin sentezinden sorumlu bir enzimdir. O. onites'de bu enzimin gen dizi bilgisi ve ifade karakteristiğinin incelenmesi, tıp, kozmetik vb. endüstrilerde ham madde olarak terpenlerin sentezinin arttırılmasına katkı sağlayabilir. Bu çalışmada, $O$. onites'de TPS-6 geninin kısmi olarak klonlanması ve dizilenmesi amaçlandı. $O$. onites'den toplam RNA izolasyonu TRI Reagent solüsyonu ile gerçekleştirildi. O. onites mRNA'ları Ters Transkripsiyon Yöntemi ile cDNA'lara dönüştürüldü. TPS-6 geninin orta bölgesi, TPS-6 genine özel dizayn edilmiş dejeneratif primerler kullanarak PCR yöntemiyle çoğaltıldı. 481 bç büyüklüğünde çoğaltılmış DNA parçaları elde edildi ve PGEM T Easy plazmit vektörüne T4 DNA ligaz enzimiyle eklendi. Rekombinant plazmit vektör XLI-Blue konakçı hücresine (E. coli) transfer edildi ve klonlanmış DNA dizilendi. Kısmi TPS-6 DNA dizisi NCBI gen bankası veri tabanında TPS-6 geni için doğrulandı ve bir kayıt numarası ile (MF983853) ile kaydedildi. Elde edilen DNA dizisi, EBI veri tabanındaki InterProScan ve Clustal Omega programları ile analiz edildi. Analiz sonuçları, bu dizi bilgisinin TPS-6'ya özgü siklizasyon reaksiyonlarını katalizleyen spesifik bir motife (DXXDD) sahip olduğunu gösterdi. Diğer bitki TPS-6 genler ile karşılaştırmak için filogenetik dendrogram çizildi. O. onites TPS-6 dizisinin, $O$. vulgare TPS-6'ya diğer bitki TPS-6'larına göre daha yakın olduğu tespit edildi. Elde edilen gen dizi bilgisi, ifade analizleri kullanılarak bu genin verimliliğinin arttırılmasında biyoteknolojik araştırmalara rehberlik edecektir.
\end{abstract}

Anahtar kelimeler: Origanum onites, TPS-6, Gen klonlama, DNA dizileme.

\section{Introduction}

Oregano, Origanum onites L. (Linnaeus), is a member of Lamiaceae family (Davis et al. 1988, Başer 1993, Sarihan et al. 2006) and a Mediterranean plant whose Turkey distributional range coincides to western Anatolian. O. onites, containing 2-3\% volatile (essential) oil (Baytop 1999) and is one of the major export products of Turkey. Turkey has a dominant position in worldwide trade of oregano and keeneps control of $70 \%$ of world trade in annual production of oregano (Fak1ll 2010). The oil content of the species includes some phenolic 
derivatives such as carvacrol, thymol, linalool etc. (Baytop 1999, Kaloustian et al. 2003, Baydar 2005) and therefore used as antioxidant, antibiotic, antibacterial, muscle relaxant, expectorant, diaphoretic, body tonic, analgesic, nerve strengthening, high-grade lubricants, biofuels and a component of agricultural chemicals (Aligiannis et al. 2001, Lambert et al. 2001, Poyraz 2015, Tokul 2015, Jiang et al. 2016, Lopez et al. 2016). Terpenes and terpenoids are the primary constituents of essential oils of many plants and flowers (Huber et al. 2005, Tholl 2006, Degenhardt et al. 2009, Yang et al. 2013) and the global industry recovers about 3 million tones terpenes (Mewalal et al. 2016). The terpene synthases have an important role in volatile oils synthesis (Tholl 2006, Zhang et al. 2016). The class I terpene synthases (TPSs) are classified as mono-, sesqui- and diterpene synthases according to their catalytically preferred substrates geranyl diphosphate, farnesyl diphosphate and geranylgeranyl diphosphate, respectively. Terpene synthase-6 (TPS-6) is a kind of sesqui terpenes (Lange 2015). Characterization and genetically identification of various terpene synthases from different aromatic plants in future will provide important advantages in increasing of terpene production in industry. In this study, we described the partial cloning from and estimation of putative terpene synthase- 6 gene in $O$. onites.

\section{Materials and Methods}

\section{Plant material}

$O$. onites seeds were provided by Prof. Dr. Hasan Baydar from Süleyman Demirel University (Isparta, Turkey). Seeds were germinated and grown on potting mixture containing peat, perlite and vermiculite $(3: 1: 1)$ at $25^{\circ} \mathrm{C}$ under a $16 \mathrm{~h}$ photo-period of cool white fluorescent illumination in a growth chamber (Sanyo, Japan). The germinated plant leaves were collected and used in RNA isolation.

\section{$\underline{R N A}$ isolation and reverse transcription}

RNA isolation was performed using a modified guanidine isothiocyanate method (Poyraz et al. 2010). $O$. onites leaves were ground to fine powder and transferred to $2 \mathrm{ml}$ tubes. The obtained total RNA was extracted with a TRI Reagent ${ }^{\circledR}$ at room temperature and recovered by isopropanol precipitation method. The quantity and purity of the RNA samples were determined following spectrophotometric measurements (Nano-drop UV spectrophotometer, Shimadzu, Japan) and integrity of total RNA sample was confirmed by denaturing agarose gel electrophoresis. Reverse transcription was performed according to the commercial kit (RevertAid First Strand cDNA Synthesis Kit, Fermentas, Glen Burnie, MD, USA) and the harvested cDNA (complementary DNA) was stored at $-20^{\circ} \mathrm{C}$ until use.

\section{Cloning of the middle region of $c D N A$}

We used conservative regions obtained from alignment data of other plant TPS-6 sequences in National Center for Biotechnology Information (NCBI) for primer designing. The alignment analysis was performed using CLUSTAL Omega 1.2.4 software. A pair of degenerative primers was designed as Forward: 5' SGMTTTCGMCTMCTTCGACAACA-3' and Reverse: 5'-TAGCAYTCCACMASTCTATCCCK-3'. The design primers were used for amplification in polymerase chain reaction (PCR). The $25 \mu \mathrm{l}$ PCR reaction mixture contained 10x PCR buffer $2.5 \mu \mathrm{l}, 25 \mathrm{mM} \mathrm{MgCl}_{2} 3 \mu \mathrm{l}, 2.5 \mathrm{mM}$ deoxyribonucleotide triphosphates $2 \mu \mathrm{l}, 2.5 \mu \mathrm{M}$ P1 and P2 $2.5 \mu 1$, respectively, cDNA $5 \mu 1$, ddH2O $7.3 \mu 1$, and $1 \mathrm{U}$ Taq polymerase (Promega, WI, USA). The conditions for PCR were as follows: pre-denaturalization at $94^{\circ} \mathrm{C}$ for $2 \mathrm{~min}$, denaturalization at $94^{\circ} \mathrm{C}$ for $40 \mathrm{sec}$, annealing at $56.5^{\circ} \mathrm{C}$ for $50 \mathrm{sec}$, extension at $72^{\circ} \mathrm{C}$ for $50 \mathrm{sec}, 35$ cycles and the final extension at $72^{\circ} \mathrm{C}$ for $7 \mathrm{~min}$. The amplified TPS-6 cDNA was purified by QIAquick Gel Extraction Kit (Qiagen, Hilden, Germany). The harvested TPS-6 gene fragment was cloned into pGEM-T Easy vector system (Promega, WI, USA) using T/A cloning system (without restriction enzymes). The recombinant vector was transferred into Escherichia coli XL1B strain. The bacteria culture was incubated at $37^{\circ} \mathrm{C}$ over-night. E. coli colonies containing positive clones were selected after growing on LB medium supplemented with ampicillin $(50 \mathrm{mg} / \mathrm{ml}), \mathrm{X}-\mathrm{Gal}(0.008 \%)$. The positive colonies including recombinant plasmid vectors were selected on transformation plate and transferred to master plate for confirmation. The recombinant plasmids in E. coli cultures were isolated using Qiagen Plasmid Miniprep Kit (Qiagen, Hilden, Germany), and subsequently used to sequence the middle region of cDNA. DNA sequencing of the partial TPS-6 was carried out two times by commercial sequencing service (Macrogene, Korea) using vector specific forward and reverse primers.

\section{Bioinformatics analyses}

The obtained DNA sequence data was verified for TPS-6 genes in NCBI database using The Basic Local Alignment Search Tool (BLAST). DNA sequences of other plant species for TPS-6 gene were obtained from NCBI database (www.ncbi.nlm.nih.gov). The confirmed partial TPS-6 gene sequence was registered to NCBI GenBank and the accession number was obtained. The DNA sequence was translated to protein sequence and the multiple protein sequence alignments were carried out with ClustalW program (www.ebi.ac.uk/clustalw) and Gene Tool $^{\mathrm{TM}}$ (Biotools Inc., USA). The domain and motif analysis of the partial TPS-6 protein sequence were performed using Inter-ProScan Analysis Program in EBI (European Bioinformatics Institute) database. The phylogenetic dendrogram for comparison with other plant TPS-6 genes was drawn according to Maximum Likelihood Analysis Method using MEGA 6.06 software.

\section{Results and Discussion}

Terpenes and terpenoids are the primary constituents of essential oils of many plants and flowers. Essence oils including terpenes are used as natural flavor additives for food, in perfumery, aromatherapy and in traditional and alternative medicine (Poyraz 2007). O. onites is an 
important aromatic plant and is the most common commercially cultivated plant in Turkey (Poyraz 2007). In this study, we cloned a partial of $O$. onites terpene synthase-6 (TPS-6) gene and performed DNA sequence analyses. We obtained a $\sim 481 \mathrm{bp}$ band represented partial TPS-6 using PCR method (Fig. 1). The DNA fragment obtained by PCR method was ligated to PGEM-Teasy vector and transformed to XL1-B E. coli strain. The ligated DNA fragment in recombinant plasmid was confirmed by colony PCR methods and the same DNA fragment size ( 481bp) was observed. The DNA sequence of partial TPS-6 gene was obtained using a commercial DNA sequencing service. DNA sequence was translated to amino acid (160 AA) sequence using GeneTool $^{\mathrm{TM}}$ software and confirmed in NCBI database (Fig. 2). The partial $O$. onites TPS-6 gene sequence was submitted to NCBI GenBank and registered (GenBank Accession number: MF983853).

The huge variation of secondary metabolites produced by plants is considered as attractive and amazing by scientists (Köllner et al. 2004, Jiang et al. 2016). Oregano terpenes were reported to have a protective role in suppression of inflammation (Lopez et al. 2016). Terpene synthase genes in aromatic plants encode attendant enzymes in the synthesis of plant essential oils (Bayrak 2006). Terpenes comprise a very large class of secondary metabolites in aromatic plants and are formed by different functions in basic and specialized metabolism (Chen et al. 2004).

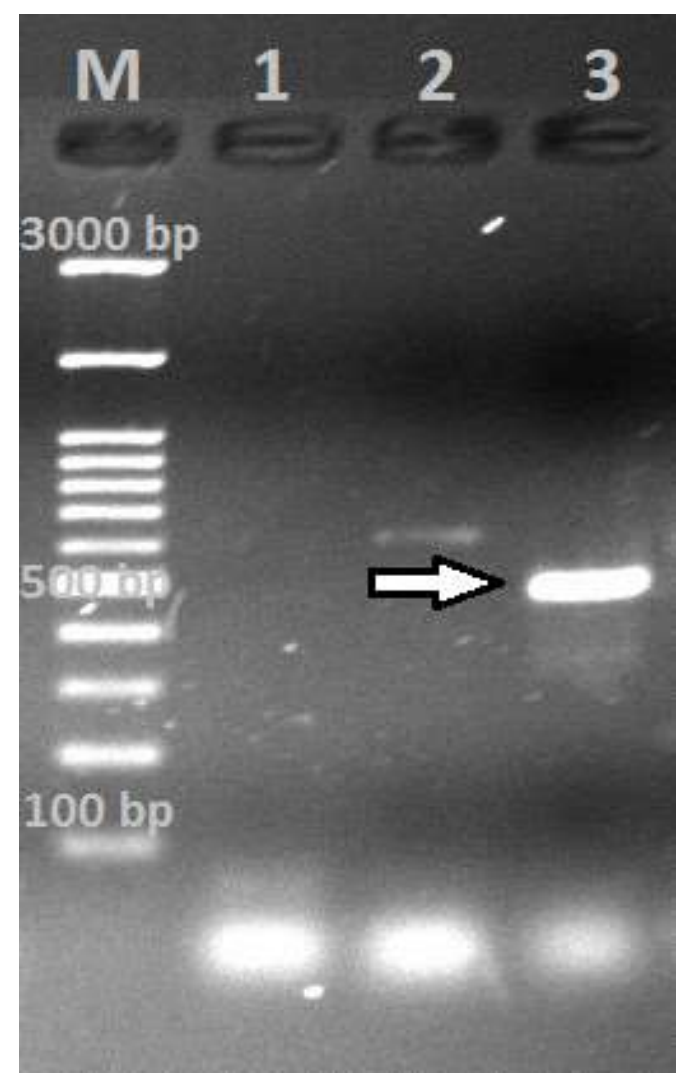

Fig. 1. PCR result for partial terpene synthase $6(T P S-6)$ from $O$. onites. 1-2: the negative results (off the record data), 3: 481bp PCR bands, M: 100bp plus DNA ladder.

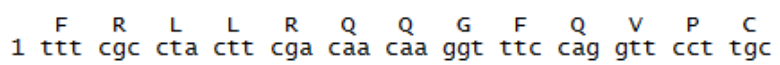

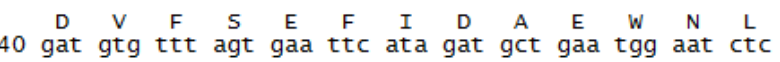
79 acg gag tca ata gca tac gac att cáa ggg ata ttg agc

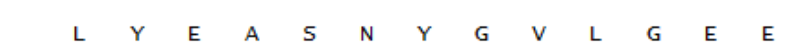
118 tta tac gag gca tca aat tat gga gtg ctc gga gag gaa

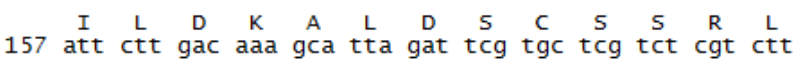

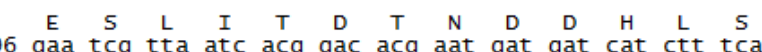
$\begin{array}{lllllllllllll}R & Q & V & K & E & A & L & K & I & P & I & S & K\end{array}$ 235 aga caa gtt aag gaa gct cta aag atc cca att agc aag $\begin{array}{ccccccccccccc}\text { T } & \text { L } & T & R & \text { L } & G & A & R & K & F & I & 5 & M \\ \text { act } & \text { cta } & \text { aca } & \text { agg } & \text { ttg } & \text { gga } & \text { gca aga } & \text { aag } & \text { ttc } & \text { att } & \text { tct } & \text { atg }\end{array}$

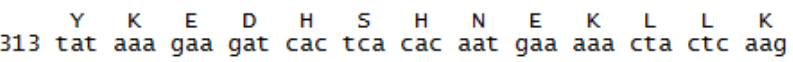

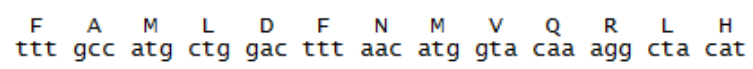

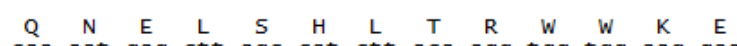
391 caa aat gag ctt agc cat ctt aca agg tgg tgg aag gaa

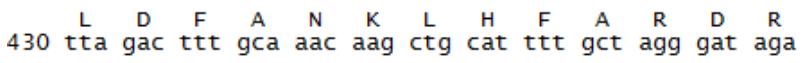
$v$
gtg gtg ga

Fig. 2. DNA sequence and the translated amino acid sequence of partial TPS-6 gene. Translated nucleotide number 480 (160 AA). The predict position for the complete $O$. onites TPS- 6 mRNA: 367-847.

Terpenes are a large class of hydrocarbon compound constructed from five-carbon isoprene units (Pichersky 2006). The diversity and variability of terpenes are due to the terpene synthases variation. Terpene synthase enzyme family unlike the majority of the enzymes involved in the biosynthesis of secondary metabolites, are renowned for being able to convert a single substrate into many different products (Keszei et al. 2010). The obtained DNA sequence data in our study is similar with the other aromatic plants, but not completely same (Fig. 3). Therefore, this specific data represents $O$. onites TPS-6 gene. This DNA sequence may be used on transcription analysis studies without all gene sequence. The molecular and biochemical studies about terpene synthases provide opportunities for detailed functional evaluations of terpene metabolites in plants (Tholl 2006).

For comparison with the other plant TPS-6 AA sequences, the multiple protein sequence alignment was performed using Clustal W program (Fig. 3). The domain and motif analysis of the partial TPS- 6 gene were performed using InterProScan Analysis Program (Fig. 4). We determined that the obtained DNA sequence had a terpenoid cyclases/Protein prenyltransferases superfamily domain sequence (alpha-aplha toroid), terpene synthase $\mathrm{N}$ terminal domain sequence and terpene synthase magnesium ion (metal) binding domain sequence. Analysis results confirmed that the amino acid sequence translating from the cloned partial DNA includes specific motifs and domains of a TPS-6 enzyme family (Fig. 4). In addition, there is a specific motif (DXXDD) in the partial TPS-6 gene (Fig. 3) and catalyzes cyclization reactions (Bolhman et al. 1998). 
Thymus vulgaris_TPS6

Valeriana_officinalis_TPS6

Zea_mays_TPS6

Zingiber_zerumbet_TPS6

Matricaría_chamomilla_tPS6

Origanum_vulgare_TPS6

Origanum_onites_TPS6

Thymus_vulgaris_TPS6

Valeriana_officinalis_TPS6

Zea_mays_TP56

Zingiber_zerumbet_TPS6

Matricaria_chamomilla_TPS6

Origanum_vulgare_TPS6

Origanum_onites_TPS6

Thymus_vulgaris_TPS6

Valeriana_officinalis_TPS6

Zea_mays_TPS6

Zingiber_zerumbet_TPS 6

Matricaría_chamomillla_TPS6

Origanum_vulgare_TPS6

Origanum_onites_TPS6
FRLLROHGFNWSOEIFDCFKNEKGSDFDETLIGEDTKATLOLYEASFHLREGENTLELAR FIYLRQHGFDVPQDIFKTFMDDQGKFKG--ELSKDINAMLYLYEASYLSTPKDDIMDEAR FYLLRKCGYDVSSDVFLKFKDQLGNFVE-----ADTRSLLSLYNAAFLRIHGETVLDEAI FRLLRQHGYNSTDTFNKFRDDNGSFIS--TLKRDAKGLLSLYNVSYLATHGETILDEAN FRLLRQQGFNUSSGVFKDYMDEKGNFKE--SLCNDAQGILALYEAAYMRVEGETRLDKAL FRLLROOGFHVPFDVLSEFIDAEGNLTE--SIAYDIQGILSLYEASNYGVLGEEILDKAL FRLLRQQGFQVPCDVFSEFIDAEWNLTE--SIAYDIQGILSLYEASNYGVLGEEILDKAL * **: *:* : : : * . ***::

QISTKYLQKKVDEGSINDENLSSWIRHSLDLPLHWRIORLEARWFLDAYAAREDKNPLIF DFSTKYLKEYAEKNNDNNEFLKKLVIHSLQLPLRWWVVSLEARWFIDNYENKQDNNPTLL SFTMRVLQDRLEH---LESPLAEEVSSALDTPLFRRVGTLEMKDYIPIYEKDAKQNKSIL YFTKSQLVSLLSE---LEOPLETOVSLFLEVPLCRRIKSLLARIYIPIYOKDAMRNDVIL EFTKVHLDIISKDP-SCDSYLRTRVHQALKQPLRRRLARIEALHYMPVYQQDSSHNEVLL DSCSSRLESLITDT-D-DDRLSROVKEALKIPISKTLTRLGARKFISMYKEDDSHNEKLL DSCSSRLESLITDT-N-DDHLSROVKEALKIPISKTLTRLGARKFISMYKKEDHSHNEKLL :. $*$ : *. *: : : : : * *

ELTKLDFNIIQATQQEELKEVSRIWINNSRLAEKLPFVRDRVVECQFAKLDYNILQAIHLEDLKYTSRWWKSTSLVEKLSFARDRLVENEFAKLNFNLLQLRYSSELKECTTWWKELRVESNLSFVRDRIVEVY ELAKLDFNLLOSLYQEELKKVSIWWNDLALAKSLKFIRDRIVEAKLAKVDFSVLQS/HKKELSHICKWWKDLDLONKLPWRDRWEGKFAMLDFNNQRLHQNELSHLTRLWKELDFANKLPFARDRLVECKFANLDFN'WQRLHQNELSHLTRWWKELDFANKLHFARDRWEC$::::::^{*} \quad:^{*} \quad * *:, .^{*}: * * *:^{* *}$

Fig. 3. The multiple protein sequence alignment for partial $O$. onites TPS-6 gene with other plant TPS-6s. The species and corresponding accession number are as follows: T. vulgaris TPS-6 (JX946357), V. officinalis TPS-6 (JX494704), Z. mays TPS-6 (NM_001112204), Z. zerumbet TPS-6 (AB247335), M. chamomilla TPS-6 (KJ020283), O. vulgare TPS-6 (GU385969). $71-75$ AA positions have DXXDD motif.

\section{Domains and repeats}

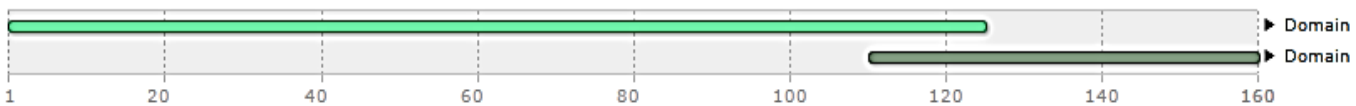

\section{Detailed signature matches}

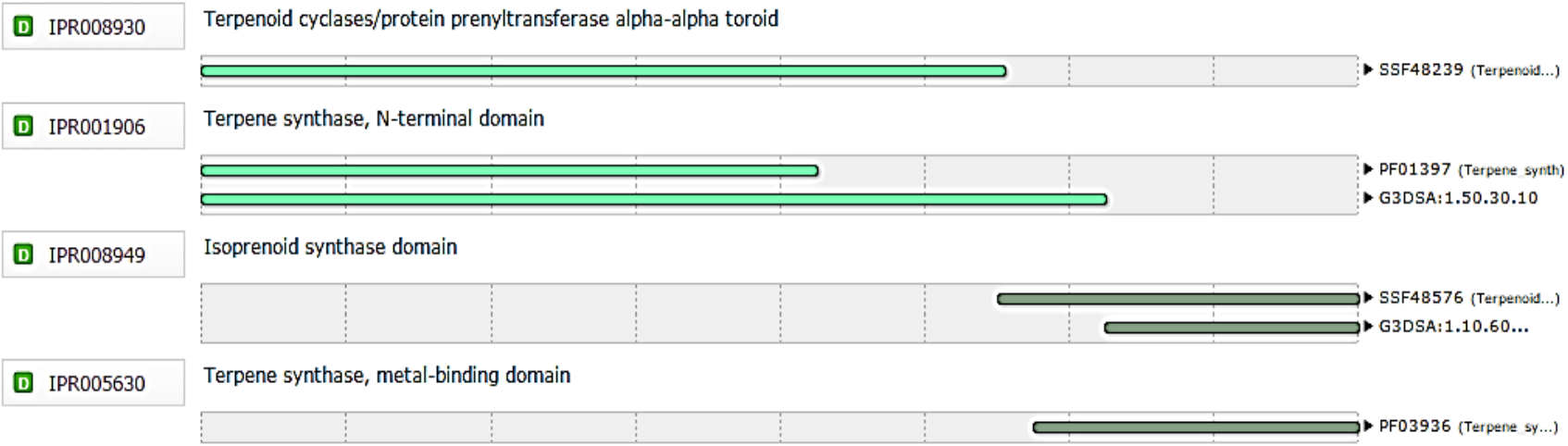

Fig. 4. InterProScan Analysis of the partial TPS-6 gene. SSF48239: Terpenoid cyclases/Protein prenyltransferases superfamily member (alpha-aplha toroid), PF01397: Terpene synthase N terminal domain, PF03936: Terpene synthase magnesium ion (metal) binding domain.

The phylogenetic analysis of $O$. onites partial TPS-6 gene was drawn for comparison with the similar overlapping sequences of other plant TPS-6s (Fig. 5). We observed that the $O$. onites TPS-6 gene sequence is very close to $O$. vulgare TPS-6 gene than other plant TPS-6s. Interestingly, although Thymus sp. is close to Origanum sp., O. onites and $O$. vulgare TPS-6 sequences are located far to Thymus vulgaris TPS-6 on the dendrogram (Fig. 5). This result shows that
TPS-6 enzymes may include the high gene polymorphism among species and genus.

The sequence data of the middle region of TPS- 6 gene is the first reported data for $O$. onites. This cloned region includes the characteristic motif for TPS- 6 gene and it is specific for $O$. onites. This data may provide an important advantage in the transcriptome analyses without all gene sequence for TPS-6. It may be used in determination of enzyme activity analysis in different stress conditions. 


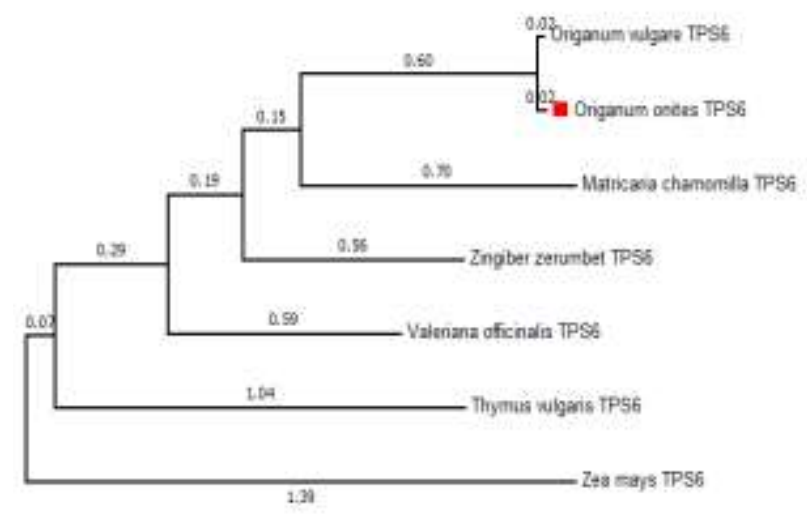

$\stackrel{02}{1}$

Fig. 5. The phylogenetic dendrogram of partial TPS-6 genes of $O$. onites and other plants using Maximum Likelihood Analysis Method (MEGA 6.06). The highest identity rate of $O$. onites TPS-6 is $96 \%$ with $O$. vulgare TPS- 6 and the distance value is 0.02 . The species and corresponding accession number were given in Fig. 3.

Terpene synthase genes in aromatic plants encode attendant enzymes in synthesis of plant essential oils (Bayrak 2006). The characterization of terpene synthase genes was achieved using a method based on the homology within these

\section{References}

1. Aligiannis, N., Kalpoutzakis, E., Mitaku, S. \& Chinou, B.I. 2001. Composition and antimicrobial activity of the essential oils of two Origanum species. Journal of Agricultural and Food Chemistry, 49: 4168-4170.

2. Attaran, E., Rostás, M. \& Zeier, J. 2008. Pseudomonas syringae Elicits Emission of the Terpenoid (E,E)-4,8,12Trimethyl-1,3,7,11-Tridecatetraene in Arabidopsis Leaves Via Jasmonate Signaling and Expression of the Terpene Synthase TPS4. Molecular Plant-Microbe Interactions, 21/11: 1482-1497.

3. Başer, K.H.C., Özek, T., Tümen, G. \& Sezik, E. 1993. Composition of the essential oils of Turkish Origanum species with commercial importance. Journal of Essential Oil Research, 5: 619-623.

4. Baydar, H. 2005. The effects of different harvest dates on essential oil content and essential oil composition in Origanum minutiflorum O. Schwarz et. P.H. Davis. Akdeniz University Journal of the Faculty of Agriculture, 18: $175-178$

5. Baytop, T. 1999. Türkiye'de Bitkiler ile Tedavi, Geçmişte ve Bugün, ilaveli 2. bask1, Nobel Tıp Kitabevleri, İstanbul.

6. Bayrak, A., 2006. Gida aromalarl, Gida Teknolojisi Derneği, Yayın no: 32, Ankara

7. Bolhman, J., Gilbert, M.G. \& Rodney, C., 1998. Plant terpenoid synthases: Molecular biology and phylogenetic analysis. Proceedings of the National Academy of Sciences, 95: 4126-4133.

8. Chen, F., Dae-Kyun, R., Petri, J., Gershenzon, J., Bohlmann, J., Pichersky, E. \& Tholl, D. 2004. Characterization of a root-specific Arabidopsis terpene enzymes (Wallaart et al. 2001, Huber et al. 2005). The identification and characterization of terpene synthases in Daucus carota roots were performed in 2015.

The role of recombinant TPS genes in carrot aroma biosynthesis was investigated (Yahyaa et al. 2015). The partial TPS-6 gene sequence may be used as a probe in Real Time PCR method and has an important potential for the development of high yield plants. The TPS- 6 gene efficiency in $O$. onites may be increased and can be used in development of a genetically modified aromatic plant. Terpenoids have been implicated in plant defenses, but their direct role in resistance against microbial pathogens is not clearly defined (Attaran et al. 2008). Attaran et al. (2008) examined a possible role of terpenoid metabolism in the induced defense of $A$. thaliana plants against leaf infection with the bacterial pathogen Pseudomonas syringae pv. maculicola. They studied effects of mutant TPS-4 genes on jasmonic acid (JA)-dependent signaling (Attaran et al. 2008). The DNA sequence data of terpene synthase genes are going to be used for gene expression analyses. Finally, the studies about genetical identification of different terpene synthases from various aromatic plants will conduce to global science, biotechnology and agricultural industry. Furthermore, efforts to increase terpene production will contribute to medicine and cosmetics industry.

synthase responsible for the formation of the volatile monoterpene 1,8-cineole1. Plant Physiology, 135: 19561966.

9. Degenhardt, J., Köllner, T.G. \& Gershenzon, J. 2009. Monoterpene and sesquiterpene synthases and the origin of terpene skeletal diversity in plants. Phytochemistry, 70(1516): 1621-1637.

10. Davis, P.H., Mill, R.R. \& Tan, K. 1988. Flora of Turkey and the Aegean Islands, Edinburgh Univ. Press, 10, 209, Edinburgh.

11. Fakıllı, O. 2010. Türkiye'de Kekik Adı ile Anılan Bitkiler Konusunda Yapılan Çalışmaların Envanteri. Master Thesis, Graduate School of Sciences, Çukurova University.

12. Huber, D.P. Philippe, R.R., Godard, K.A., Sturrock, R.N. \& Bohlmann, J. 2005. Characterization of four terpene synthase cDNAs from methyl jasmonate-induced Douglasfir, Pseudotsuga menziesii. Phytochemistry, 66: 14271439.

13. Jiang, Z., Kempinski, C. \& Chappeil, J. 2016. Extraction and Analysis of Terpenes/Terpenoids. Current Protocols in Plant Biology, Doi:10.1002/cppb.20024.

14. Keszei, A., Brubaker, C.L., Carter, R., Köllner, T., Degenhardt, J. \& Foley, W.J. 2010. Functional and evolutionary relationships between terpene synthases from Australian Myrtacea. Phytochemistry, 71: 844-852.

15. Kaloustian, J., El-Moselhy, T.F. \& Portugal, H. 2003. Chemical and thermal analysis of the biopolymers in thyme (Thymus vulgaris). Thermochimica Acta, 401/2 77-86. 
16. Köllner, T.G., Schnee, C., Gershenzon, J. \& Degenhardt, J. 2004. The variability of sesquiterpenes emitted from two Zea mays cultivars is controlled by allelic variation of two terpene synthase genes encoding stereoselective multiple product enzymes. The Plant Cell, 16: 1115-1131.

17. Lambert, R.J.W., Skandamis, P.N., Coote, P.J. \& Nychas, G.J.E. 2001. A study of the minimum inhibitory concentration and mode of action of oregano essential oil, thymol and carvacrol. Journal of Applied Microbiology, 91: 453-462.

18. Lange, B.M. 2015. The evolution of plant secretory structures and emergence of terpenoid chemical diversity. Annual Review of Plant Biology, 66: 139-159.

19. López, N L, Nair V., Bang W.Y., Zevallos L.C. \& Heredia, J.B. 2016. Protective role of terpenes and polyphenols from three species of Oregano (Lippia graveolens, Lippia palmeri and Hedeoma patens) on the suppression of lipopolysaccharide-induced inflammation in RAW264.7 macrophage cells. Journal of Ethnopharmacology, 187: 302-312.

20. Mewalal, R., Rai, D.K., Kainer, D.K., Chen, F., Külheim, C., Peter, G.F. \& Tuskan, G.A. 2016. Plant-Derived Terpenes: A Feedstock for Specialty Biofuels. Trends in Biotechnology,

Doi: http://dx.doi.org/10.1016/j.tibtech.2016.08.003.

21. Pichersky, E. 2006. Biosynthesis of plant volatiles: nature's diversity and ingenuity. Science, 311(5762): 808-811.

22. Poyraz, I., Sozen, E. \& Arslanyolu, M. 2010. Isolation of quality total RNA from the aromatic plant Origanum onites. Zeitschrift für Naturforschung C, 65: 266-270.

23. Poyraz, I. 2007. Origanum onites'de Mitojenler Tarafindan Aktive Edilen Protein Kinaz Kinaz (MAPKK) Enzim Ailesi Üyelerinden Birinin Klonlanmasl ve Enzimatik Olarak Tanımlanmast. PhD. Thesis, Graduate School of Science, Anadolu University.
24. Poyraz, I. 2015. Molecular cloning and characterization of a mitogen-activated protein kinase kinase (OoMAPKK1) in Origanum onites L. (Lamiaceae). Journal of Plant Biochemistry and Biotechnology, 24(1): 75- 83.

25. Sarıhan, E.O., İpek, A., Arslan, N. \& Gürbüz, B. 2006. Farklı sira aras1 ve sira üzeri mesafelerinin kekik (Origanum vulgare var. hirtum)'de verim ve verim öğeleri üzerine etkisi. Ankara Üniversitesi Ziraat Fakültesi Tarım Bilimleri Dergisi, 12(3): 246-251.

26. Tholl, D. 2006. Terpene synthases and the regulation, diversity and biological roles of terpene metabolism. Current Opinion in Plant Biology, 9: 297-304.

27. Tokul, H.E. 2015. İzmir kekiği (Origanum onites L.)'nde farklı su ve azot uygulamalarının verim ve kalite üzerine etkileri ile bunların fizyolojik denetimi. PhD. Thesis, Graduate School of Science, Ege University.

28. Wallaart, T.E., Bouwmeester, H.J., Hille, J., Poppinga, L. \& Maijers, N.C.A. 2001. Amorpha-4,11-diene synthase: cloning and functional expression of a key enzyme in the biosynthetic pathway of the novel antimalarial drug artemisinin. Planta, 212/3: 460-465.

29. Yahyaa, M., Tholl, D., Cormier, G., Jensen, R., Simon, P.W. \& Ibdah, M., 2015. Identification and Characterization of Terpene Synthases Potentially Involved in the Formation of Volatile Terpenes in Carrot (Daucus carota L.). Roots. Journal of Agricultural and Food Chemistry., 63: 4870-4878.

30. Yang, C.Q., Wu, X.M., Ruan, J.X., Hu, W.L., Mao, Y.B., Chen, X.Y. \& Wang, L.J. 2013. Isolation and characterization of terpene synthases in cotton (Gossypium hirsutum). Phytochemistry, 96: 46-56.

31. Zhang, P., Fuentes, S., Siebert, T., Krstic, M., Herderich, M., Barlow, E.W.R. \& Howell, K. 2016. Terpene evolution during the development of Vitis vinifera L. cv. Shiraz grapes. Food Chemistry, 204: 463-474. 